\title{
INVESTIGATION OF THE EFFECTS OF KIGELIA AFRICANA (LAM.) BENTH. EXTRACTS ON TM3 LEYDIG CELLS
}

\author{
NELISIWE PRENATE MASUKU, SOGOLO LUCKY LEBELO* \\ Department of Life and Consumer Sciences, University of South Africa, Cnr Christiaan de Wet and Pioneer Ave, Private Bag X6, \\ Florida, 1710, South Africa. Email: lebelol@unisa.ac.za
}

Received: 16 May 2019, Revised and Accepted, 31 July 2019

\section{ABSTRACT}

Objective: The study reports the effects of acetone, methanol, and aqueous Kigelia africana extracts on the TM3 Leydig cells.

Methods: The total phenolic contents were determined using Folin-Ciocalteu's method. Antioxidant activity was determined using 1,1-diphenyl-2picrylhydrazyl assay and flavonoid content assessed using quercetin as standard. Cell viability and cytotoxicity were assessed.

Results: Total phenolic and flavonoid contents of the extracts were analyzed. Acetone extracts showed highest total phenolic content $(105 \pm 3.65$ mg gallic acid equivalent [GAE]/g) followed by methanol extracts $(10.64 \pm 0.32 \mathrm{mg} \mathrm{GAE} / \mathrm{g}$ ) and, last, the water extract with the total phenolic content of $4.27 \pm 0.65 \mathrm{mg} \mathrm{GAE} / \mathrm{g}$. The same trend was observed with total flavonoid content where results recorded for acetone, methanol, and water extracts were $3.63 \pm 0.20 \mathrm{mg} / \mathrm{g}$ quercetin equivalent (QE), $0.16 \pm 0.01 \mathrm{mg} \mathrm{QE} / \mathrm{g}$, and $0.01 \pm 0.00 \mathrm{mg} \mathrm{QE} / \mathrm{g}$, respectively. The three extracts showed lower IC 50 values compared to ascorbic acid $(0.143 \pm 0.05 \mathrm{mg} / \mathrm{ml}, 0.023 \pm 0.004 \mathrm{mg} / \mathrm{l}$, and $0.043 \pm 0.03 \mathrm{mg} / \mathrm{ml}$ for acetone, methanol, and water extracts, respectively). At $0.5 \mathrm{mg} / \mathrm{ml}$ of acetone extract, there was an increase in the testosterone production compared to the control.

Conclusion: The findings of this study showed that $K$. africana could be recommended for use in the treatment of male infertility.

Keywords: Kigelia africana (Lam.) Benth., Antioxidants, Cytotoxicity, TM3 Leydig cells testosterone.

(C) 2019 The Authors. Published by Innovare Academic Sciences Pvt Ltd. This is an open access article under the CC BY license (http://creativecommons. org/licenses/by/4. 0/) DOI: http://dx.doi.org/10.22159/ajpcr.2019.v12i10.34163

\section{INTRODUCTION}

Medicinal plants are used by millions of people worldwide for alleviation and treatment of various diseases and they have significantly contributed to the improvement of human health [1]. Approximately $80 \%$ of world population use traditional medicines for primary health care [2]. Preference of medicinal plants over synthetic medicines is due to the ease of access, low costs, and relatively less side effects. In many developing countries, the use of medicinal plants is profoundly practiced and lot of work is done to verify the efficiency and efficacy of medicinal plant extracts as claimed by traditional practitioners. Medicinal plants are believed to contain a wide range of antioxidants such as polyphenols that maintain the physiological levels of free radicals and subsequently protect tissues from detrimental effects of free radical [3]. The antioxidants present in plant products help in the stimulation of cellular defense system and biological system against oxidative damage [4]. In South Africa, medicinal plants are used to treat and manage various ailments such diabetes, hypertension, diarrhea, and male reproductive disorders [5,6]. Approximately 3000 plant species from more than 30,000 higher plant species are used in traditional medicines for the treatment of various conditions [7]. Traditional medicines are important sources of potentially useful new compounds for the development of chemotherapeutic agents [8].

Kigelia africana (Lam.) Benth. belongs to the Bignoniaceae family. The plant is commonly known as African sausage tree, liver sausage tree, or cucumber sausage tree (English), "umfongothi" (Zulu), "modukghulu" (North Sotho), and "muvevha" (Venda). The plant is widespread in Southern Africa, especially in Namibia, Botswana, South Africa, and Swaziland [9]. The different parts of K. africana are used traditionally for the treatment of various ailments. The seeds, fruits, stem bark, leaves, and roots are used for the treatment of pneumonia, malaria, diabetes, antifungal, eczema, and waist pain [10]. The leaves are also used to treat dysentery [11]. K. africana leaves are mixed with Hypoxis hemerocallidea corn, boiled and the decoction is used to treat syphilis and sores [12]. Furthermore, K. africana is used to treat wounds, dysentery, ulcer, rheumatism, syphilis, gonorrhea, and purgative [13]. The aim of the study was to determine the effect of $K$. africana (Lam.) Benth. extracts on the TM3 Leydig cells.

\section{METHODS}

Collection and preparation of plant materials

The leaves of $K$. africana (Lam.) Benth. were collected, in summer season from labeled trees of Lowveld National Botanical Garden of Mpumalanga Province, South Africa. The plant materials were dried in a cool darkroom temperature, pulverized into fine powder using laboratory electric grinder, and stored in the properly labeled polypropylene bags in a dark cool dry place until further use.

\section{Plant material extraction}

Acetone, methanol, and water were used as solvents for extractions. Three grams of the powdered leaves were weighed into $100 \mathrm{ml}$ bottles followed by addition of $30 \mathrm{ml}$ of acetone and methanol. The bottles were shaken for $30 \mathrm{~min}$ in the laboratory shaker and supernatants were decanted into centrifuge tubes. The tubes were centrifuged at $4.4 \times \mathrm{g}$ for $20 \mathrm{~min}$ and filtered through Whatman No. 1 filter paper into pre-weighed labeled glass vials. The bottles were left open under the stream of cold air in the fume cupboard for solvent evaporation. After drying, the vials were weighed again to determine the quantity of crude extracts processed.

The method of extraction with water was different from the acetone and methanol methods. Following addition of water, the concoctions were boiled on the hot plate, cooled, and filtered through Whatman No. 1 filter paper into $50 \mathrm{ml}$ centrifuge tubes. The filtrates were kept overnight in the $-80^{\circ} \mathrm{C}$ freezer and freeze-dried. After drying, the crude extracts were added into pre-weighed labeled vials to determine the quantity of crude extracts processed. 
Determination of total phenolic content

The total phenolic contents were determined according to the Folin-Ciocalteu method described by Makkar [13] and modified by Adebayo et al. [14]. The crude extracts were prepared to the concentration of $1 \mathrm{mg} / \mathrm{ml}$, from which $25 \mu \mathrm{l}$ were added in the test tubes. Extracts were treated with $250 \mu \mathrm{l}$ Folin-Ciocalteu reagent for $5 \mathrm{~min}$. After $5 \mathrm{~min}$, the reaction was stopped by adding $750 \mu \mathrm{l} 20 \%$ anhydrous carbonate. The resultant solution was made up to $5 \mathrm{ml}$ by adding $3975 \mu$ distilled water and incubated at the darkroom temperature for $2 \mathrm{~h}$. Following incubation, $300 \mu \mathrm{l}$ of solutions were transferred into 96-well plates and absorbance was read at $760 \mathrm{~nm}$ with a microplate reader. All the tests were conducted in triplicates. Gallic acid was used for the standard curve. Gallic acid in methanol was prepared to the concentrations $(1,0.5,0.25,0.125,0.063$, $0.032,0.016$, and $0.008 \mathrm{mg} / \mathrm{ml}$ ) through serial dilution. The absorbance was read and absorbance values were plotted versus concentrations. The phenolic contents of each plant extracts were determined from the standard curve and expressed as gallic acid equivalent (GAE) per gram of dried plant extracts (GAE mg/g). The total phenolic contents of the plant extracts were calculated using the formula:

\section{Total phenolic content $=\mathrm{GAE} \times \mathrm{V} / \mathrm{m}$}

Where, GAE is the concentration of gallic acid established from the calibration curve $(\mathrm{mg} / \mathrm{ml}), \mathrm{V}$ is the final volume of extract $(\mathrm{ml})$, and $\mathrm{m}$ is the weight of pure plant extract (g) [15].

\section{Determination of total flavonoid content}

The total flavonoid content of the extracts was determined according to Yadav and Agarwal [16] and slightly modified by Miliauskas et al. [14]. Briefly, the crude extracts were prepared to the concentration of $1 \mathrm{mg} / \mathrm{ml}$, from which $100 \mu \mathrm{l}$ were dissolved in $300 \mu \mathrm{l}$ methanol, to which $20 \mu \mathrm{l} 10 \%$ aluminum chloride and $20 \mu \mathrm{l}$ of $1 \mathrm{M}$ sodium acetate were added. The volume was made up to $1 \mathrm{ml}$ with $560 \mu \mathrm{l}$ distilled water. The resultant solutions were incubated at room temperature for $30 \mathrm{~min}$ and transferred into 96-well microplates. After $30 \mathrm{~min}$ incubation, the absorbance was read at $450 \mathrm{~nm}$ in the microplate reader. All the tests were conducted in triplicates. Quercetin was used for the standard curve. Different concentrations $(2,1,0.500,0.250,0.125,0.063,0.032$, $0.016,0.008$, and $0.004 \mathrm{mg} / \mathrm{ml}$ ) of quercetin were prepared through serial dilution, read and absorbance values were plotted against the concentrations. The flavonoid content of each extract was determined from quercetin standard curve. The values were expressed as mg/g quercetin equivalent (QE). The total flavonoid contents of the plant extracts were calculated using the formula:

$$
\mathrm{X}=\mathrm{C} . \mathrm{V} / \mathrm{m}
$$

Where, $\mathrm{X}$ is the flavonoid content, $\mathrm{mg} / \mathrm{g}$ is the plant extract in $\mathrm{QE}, \mathrm{C}$ is the concentration of QE established from the calibration curve $(\mathrm{mg} / \mathrm{ml})$, $\mathrm{V}$ is the final volume of extract $(\mathrm{ml})$, and $\mathrm{m}$ is the weight of the pure plant extract (g) [17].

\section{Determination of antioxidant activity (AA) using 1, 1-diphenyl-2-} picrylhydrazyl (DPPH) assay

The scavenging activity of the selected plant species was determined using the DPPH assay as previously described by Mensor et al. [18] and modified by Hamzah et al. [19]. DPPH assay was done through serial dilution of plant extracts and addition of DPPH. The plant extracts were prepared at the concentration of $1 \mathrm{mg} / \mathrm{ml}$. The assay was carried out in the 96-well plates. Initially, $100 \mu \mathrm{l}$ of methanol were added into each well followed by $100 \mu \mathrm{l}$ of each plant extracts into the first well. Plant extracts were serially diluted to the concentration of $0.500,0.250$, $0.125,0.063,0.032,0.016,0.008$, and $0.004 \mathrm{mg} / \mathrm{ml}$. DPPH solution $(0.02 \mathrm{mg} / \mathrm{ml}$ in methanol) was prepared and $100 \mu \mathrm{l}$ was added and plates were kept at darkroom temperature for $30 \mathrm{~min}$. After incubation, the absorbance was read at $517 \mathrm{~nm}$ using microplate reader. Ascorbic acid was used as a positive control. DPPH in methanol served as negative control and methanol as blank. All the samples were carried out in triplicates. Percentage of AA\% values was calculated using the formula:

$$
\mathrm{AA} \%=1-\left(\mathrm{Abs}_{\text {sample }} / \mathrm{Abs}_{\text {control }}\right) \times 100
$$

Where, Abs $_{\text {sample }}$ is the absorbance of the sample and Abs control $_{\text {in }}$ is the absorbance of the negative control. The $\mathrm{IC}_{50}$ values defined as the concentration of sample required for $50 \%$ inhibition of DPPH radical were determined from the linear regression plots, AA\% against the concentrations of the tested plant extracts $(\mathrm{mg} / \mathrm{ml})$.

\section{Cell culture conditions}

TM3 Leydig cell lines derived from mouse testes were obtained from the University of Western Cape cell culture laboratory. The cells were cultured in Dulbecco's Modified Eagle's Medium (DMEM) supplemented with $10 \%$ fetal bovine serum (FBS) (complete medium) at $37^{\circ} \mathrm{C}$ with $5 \% \mathrm{CO}_{2}$ in the incubator [20]. The cells were allowed to reach $80 \%$ confluence before passaged.

Passaging cells was carried out according to Hamzah et al. [19] with slight modifications. Briefly, the complete medium (DMEM with 10\% FBS) was discarded, washed with PBS. Following this, $3 \mathrm{ml}$ trypsin was added and incubated at $37^{\circ} \mathrm{C}$ with $5 \% \mathrm{CO}_{2}$ until cells detached, about $7 \mathrm{~min}$. To stop trypsin, $7 \mathrm{ml}$ of complete medium was added and then transferred to a $50 \mathrm{ml}$ centrifuge tube to be centrifuged at $1 \times \mathrm{g}$ for $5 \mathrm{~min}$ at $37^{\circ} \mathrm{C}$. Thereafter, the supernatant was removed, the cell pellet was resuspended in $3 \mathrm{ml}$ complete medium and each $1.5 \mathrm{ml}$ of the suspension was transferred into a new $75 \mathrm{~cm}^{2}$ cell culture flasks added $20 \mathrm{ml}$ of complete medium, written the name and date. Before kept in the incubator, the caps of the flasks were closed but not tight to allow respiration and incubated at $37^{\circ} \mathrm{C}$ with $5 \% \mathrm{CO}_{2}$

\section{Cell viability and cytotoxicity assessments}

After the cells were treated with trypsin, centrifuged, resuspended in $3 \mathrm{ml}$ fresh complete medium, they were then counted using hemocytometer [21]. The 3-(4, 5-dimethylthiazol-2-yl]-2, 5 -diphenyltetrazolium bromide (MTT) assay was carried out according to the method described by Mosmann [22] with slightly modifications. The acetone and methanol crude extracts were reconstituted in acetone and water in DMSO at the concentrations of $100 \mathrm{mg} / \mathrm{ml}$. Then, extracts were prepared to the final concentrations: $0.1,0.25,0.5,0.75$, and $1 \mathrm{mg} / \mathrm{ml}$. TM3 Leydig cells $(100 \mu \mathrm{l})$ were seeded at $5 \times 10^{3}$ cells per well of 96-well plates and treated with $100 \mu \mathrm{l}$ various concentration of plant extracts $(0.1,0.25,0.5,0.75$, and $1 \mathrm{mg} / \mathrm{ml})$ and incubated at $37^{\circ} \mathrm{C}$ with $5 \% \mathrm{CO}_{2}$ incubator. Following $24 \mathrm{~h}$ exposure, the medium was carefully removed by aspiration and $25 \mu \mathrm{l}$ MTT ( $5 \mathrm{mg} / \mathrm{ml}$ in PBS) was added to each well. The plates were then incubated for $2 \mathrm{~h}$. After $2 \mathrm{~h}$, the supernatants were carefully removed and $100 \mu$ DMSO was added to each well to dissolve formazan blue crystals produced. Afterward, the plates were incubated at darkroom temperature for $30 \mathrm{~min}$ and absorbance read at $570 \mathrm{~nm}$ and $620 \mathrm{~nm}$ for reference. Non-treated cells and MTT were used as control and blank, respectively. The samples were tested in triplicates. The percentage cell viability was calculated using the following formula:

$$
\% \text { cell viability }=\frac{\text { Mean Absorbance of treated cells }}{\text { Mean Absorbance of control }} \times 100
$$

The percentage inhibitions were then calculated using the formula:

$$
\% \text { cell inhbition }=\frac{1-\text { Mean Absorvance of treated cells }}{\text { Mean Absorbance of control }} \times 100
$$

The $\mathrm{IC}_{50}$ values were determined from the linear regression graph plotted percentage cell inhibition against test concentrations [23].

\section{Evaluation of testosterone production}

The cells $\left(5 \times 10^{3}\right.$ cells/well) were seeded in a 96-well plate, treated with various concentrations of plant extracts range of $0.1,0.25$, and $0.5 \mathrm{mg} / \mathrm{ml}$ in the presence of $1 \mu \mathrm{l}$ anti-human chorionic gonadotropin (Anti-HCG) hormone and incubated at $37^{\circ} \mathrm{C}$ with $5 \% \mathrm{CO}_{2}$ for $24 \mathrm{~h}$. After $24 \mathrm{~h}$, the production of testosterone was assessed using Testosterone 
ELISA kit according to manufacturer's instructions (ab108666Testosterone ELISA Kit).

Statistical analysis

The Microsoft Excel 2010 and Origin 6.0 Professional were used for analyzing data. Data were expressed as \pm standard deviations.

\section{Ethical consideration}

Ethical clearance was approved by the University of South Africa, College of Agriculture and Environmental Sciences Ethics Committee.

\section{RESULTS}

\section{Quantity of crude extracts}

Three grams of dried powered leaves of K. africana were extracted using acetone, methanol, and water as solvents. The percentage yield crude extracts are shown in Table 1. Water extract of $K$. africana yielded highest percentage crude extract $(9.7 \%)$ followed by methanol crude extract (2.7\%). K. africana showed lowest percentage crude extract when acetone used as solvent $(0.7 \%)$

\section{Total phenolic contents}

Table 2 and Fig. 1 show the total phenolic contents of $K$. africana extracts. The results were expressed as GAE per gram of dried plant extract (mg/g GAE). Acetone extract of K. africana had the highest total phenolic content $(105 \pm 3.63 \mathrm{mg} / \mathrm{g} \mathrm{GAE})$ followed by methanol extract

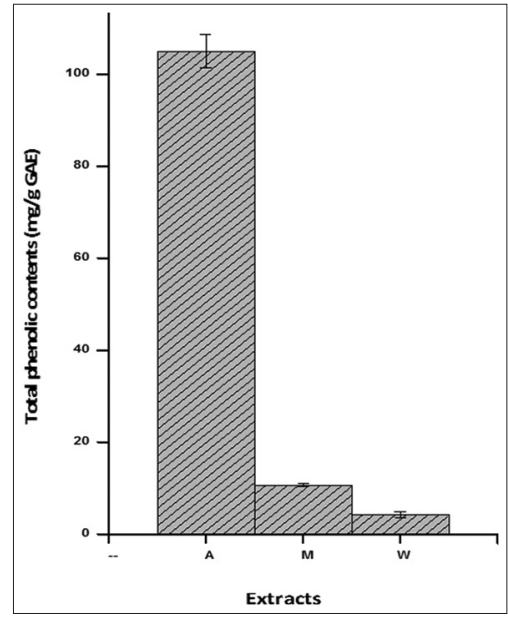

Fig. 1: Total phenolic contents of Kigelia africana extracted in acetone (A), methanol (M), and water (W). Error bars represent standard deviations of the data. Values are expressed as mean \pm standard deviation

Table 1: Percentage crude extracts yield of $K$. africana extracted using acetone, methanol, and water as solvents

\begin{tabular}{llll}
\hline \multirow{2}{*}{ Sample } & \multicolumn{2}{l}{ Yield (\%) } & \\
\cline { 2 - 4 } & Acetone & Methanol & Water \\
\hline K. africana & 0.7 & 2.7 & 9.7 \\
\hline K. africana: Kigelia africana & &
\end{tabular}

Table 2: The total phenolic contents of $K$. africana extracted using acetone, methanol, and water as solvents. Values represent mean $\pm S D$ of three determinations

\begin{tabular}{llll}
\hline Sample & \multicolumn{3}{l}{ Total phenolic content $(\mathbf{m g} / \mathbf{g ~ G A E})$} \\
\cline { 2 - 4 } & Acetone & Methanol & Water \\
\hline K. africana & $105 \pm 3.63$ & $10.65 \pm 0.32$ & $4.27 \pm 0.65$ \\
\hline K. africana: Kigelia & africana, GAE: Gallic acid equivalent, SD: Standard deviation
\end{tabular}

(10.65 $\pm 0.32 \mathrm{mg} / \mathrm{g} \mathrm{GAE}$ ). Water extracts showed the least amount of total phenolic content $(4.27 \pm 0.65 \mathrm{mg} / \mathrm{g} \mathrm{GAE})$

\section{Total flavonoid contents}

Table 3 and Fig. 2 illustrate the total flavonoid contents of $K$. africana extracts. The results showed that the highest total flavonoid content was obtained from acetone extract of K. africana $(3.63 \pm 0.20 \mathrm{mg} / \mathrm{ml}$ $\mathrm{QE})$ followed by methanol extract $(0.16 \pm 0.01 \mathrm{mg} / \mathrm{g} \mathrm{QE})$. Water extract of $K$. africana showed least amount of total flavonoid content $(0.01 \pm 0.00 \mathrm{mg} / \mathrm{g} \mathrm{QE})$.

\section{Antioxidant activities}

The AA of $K$. africana extracts was determined using DPPH radical assay and results are summarized in Table 4 . The antioxidant activities are expressed as IC $_{50}$ values. The results of the extracts of $K$. africana were compared with positive control, ascorbic acid. From the results, K. africana extracts showed lower $\mathrm{IC}_{50}$ values than that of ascorbic acid; hence, the extracts were more efficient in scavenging the DPPH radical than ascorbic acid. In terms of solvent comparisons, the methanol extract of $K$. africana had the best AA in relation to other solvents tested.

\section{Cell viability}

The TM3 Leydig cells were exposed to increasing concentrations of $K$. africana extracts. The percentage cell viabilities are presented in Fig. 3. Acetone and methanol extracts of $K$. africana showed higher percentage of viable cells at $1 \mathrm{mg} / \mathrm{ml}$, which is the highest concentration. In contrast, water extract had the higher percentage of viable cells at $0.25 \mathrm{mg} / \mathrm{ml}$.

\section{Cytotoxicity}

The results of cytotoxic effects of extracts are presented in Table 5 and Fig. 4. The cytotoxic effects are expressed as $\mathrm{IC}_{50}$ values. Water extract of $K$. africana showed lowest cytotoxicity against TM3 Leydig cells

Table 3: The total flavonoid contents of $K$. africana extracted using acetone, methanol, and water as solvents. Values represent mean $\pm S D$ of three determinations

\begin{tabular}{llll}
\hline Sample & \multicolumn{3}{l}{ Total flavonoid content $(\mathrm{mg} / \mathrm{g}$ QE) } \\
\cline { 2 - 4 } & Acetone & Methanol & Water \\
\hline K. africana & $3.63 \pm 0.20$ & $0.16 \pm 0.01$ & $0.01 \pm 0.00$ \\
\hline SD: Standard deviation, QE: Quercetin equivalent, K. africana: Kigelia africana
\end{tabular}

Table 4: DPPH IC ${ }_{50}$ values of $K$. africana extracts in acetone, methanol, and water. Values represent mean \pm SD of three determinations. Values are compared with positive control, ascorbic acid. Values are expressed as mean \pm SD

\begin{tabular}{llll}
\hline Sample & \multicolumn{4}{l}{ DPPH IC $_{\mathbf{5 0}}(\mathrm{mg} / \mathrm{ml})$} & \\
\cline { 2 - 4 } & Acetone & Methanol & Water \\
\hline K. africana & $0.143 \pm 0.052$ & $0.023 \pm 0.004$ & $0.043 \pm 0.032$ \\
\hline
\end{tabular}

Ascorbic acid: 1.474 \pm 0.319 . SD: Standard deviation, K. africana: Kigelia africana, DPPH: 1, 1-diphenyl-2-picrylhydrazyl

Table 5: $\mathrm{IC}_{50}$ values of $K$. africana extracts on the TM3 Leydig cells obtained using MTT assay. Values represent mean \pm SD

\begin{tabular}{llll}
\hline \multirow{2}{*}{ Sample } & \multicolumn{1}{l}{ MTT IC $_{\mathbf{5 0}}(\mathbf{m g} / \mathbf{m l})$} & \\
\cline { 2 - 4 } & Acetone & Methanol & Water \\
\hline K. africana & $0.332 \pm 0.112$ & $0.209 \pm 0.001$ & $0.530 \pm 0.096$ \\
\hline
\end{tabular}

SD: Standard deviation, K. africana: Kigelia africana,

MTT: 3-(4, 5-dimethylthiazol-2-yl]-2, 5-diphenyltetrazolium bromide 


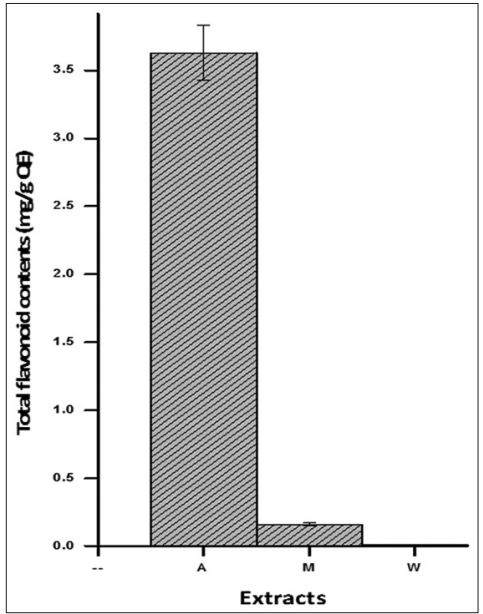

Fig. 2: Total flavonoid contents of Kigelia africana extracts extracted in acetone (A), methanol (M), and water (W). Error bars represent standard deviations of the data. Values are expressed as mean \pm standard deviation
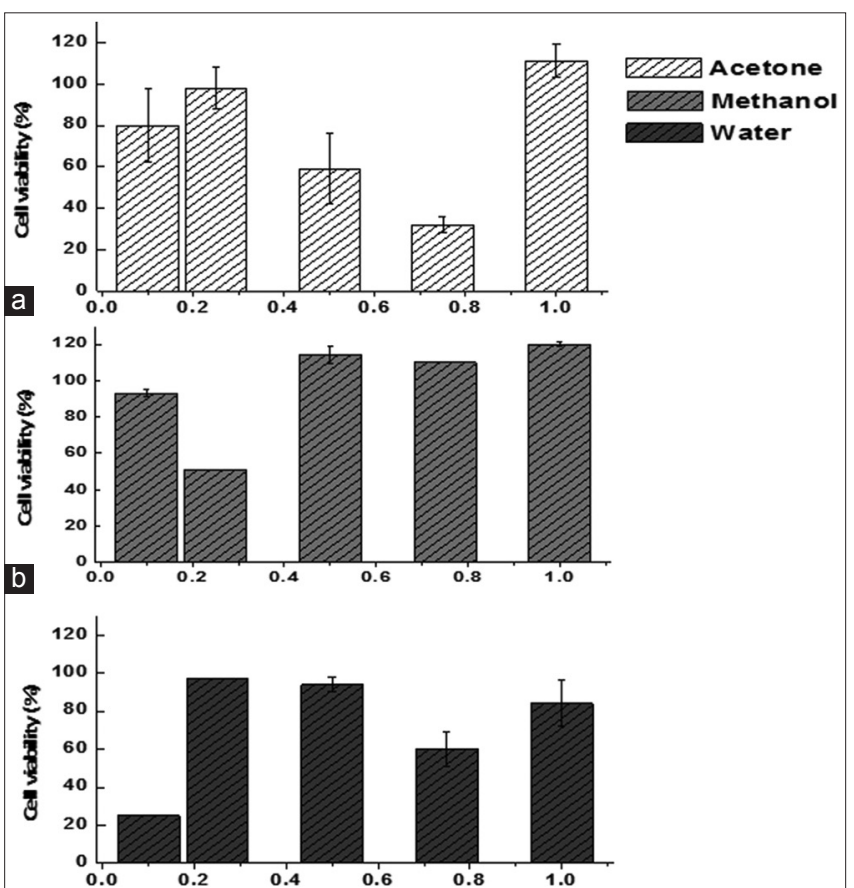

C Concentration $(\mathrm{mg} / \mathrm{ml})$

Fig. 3: Percentage cell viability of TM3 Leydig cells treated with different concentrations of Kigelia africana extract for $24 \mathrm{~h}$.

(a) $K$. africana acetone extract; (B) $K$. africana methanol extract;

(C) K. africana water extracts. Stimulated treated cells are compared with non-stimulated cells assumed $100 \%$ cell viability

at the concentration of $0.530 \pm 0.096 \mathrm{mg} / \mathrm{ml}$. In contrast, the highest cytotoxicity was observed with methanolic extract, had lower $\mathrm{IC}_{50}$ value $(0.209 \pm 0.001 \mathrm{mg} / \mathrm{ml})$.

\section{Testosterone production}

Table 6 showed the results of testosterone production in the TM3 Leydig cells exposed to selected different concentrations of $K$. africana extracts in the presence of anti-hCG hormone. From the results, the acetone and methanol extracts of $K$. africana showed increase in the testosterone production on the TM3 Leydig cells. At $0.5 \mathrm{mg} / \mathrm{ml}$, acetone extract of $K$. africana showed a significant increase in the testosterone production than in the control A.

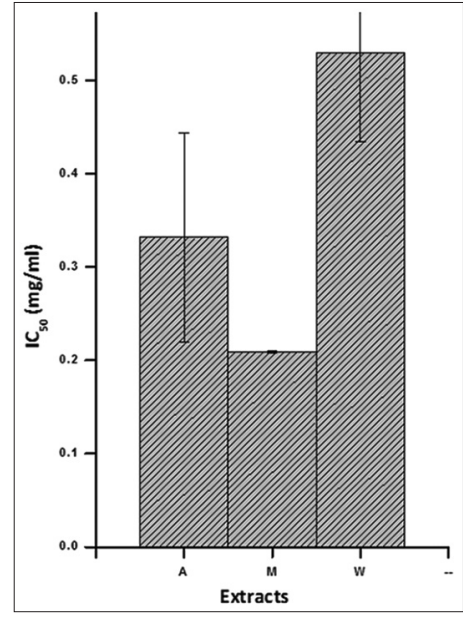

Fig. 4: $\mathrm{IC}_{50}$ values of Kigelia africana extracts on the TM3 Leydig cells obtained using MTT assay. IC $\mathrm{I}_{50}$ value represents the concentration of the extract required for $50 \%$ inhibition of cells. Error bars represent the standard deviations of the data. Values are expressed as mean \pm standard deviation. A - Acetone extract, $\mathrm{M}$ - methanolic extract, and $\mathrm{W}$ - water extract

Table 6: Testosterone production in TM3 Leydig cells exposed to selected varying concentrations of $K$. africana extracts for $24 \mathrm{~h}$ in the presence of anti-human chorionic gonadotropin hormone (hCG). Values are compared with control A and B. (-) represent not determined

\begin{tabular}{lllll}
\hline Sample & \multirow{2}{*}{$\begin{array}{l}\text { Concentration of plant } \\
\text { extracts }(\mathbf{m g} / \mathbf{m l})\end{array}$} & \multicolumn{3}{c}{ Testosterone levels $\mathbf{( n g} / \mathbf{m l})$} \\
\cline { 3 - 5 } & & Acetone & Methanol & Water \\
\hline K. africana & 0.5 & 1.407 & 0.084 & - \\
& 0.25 & 0.231 & 0.032 & 0.030 \\
& 0.1 & 0.269 & 0.019 & 0.004 \\
\hline
\end{tabular}

Testosterone control A: $0.670 \mathrm{ng} / \mathrm{ml}$, testosterone control B: $10.033 \mathrm{ng} / \mathrm{ml}$

(-) not determined. SD: Standard deviation, K. africana: Kigelia africana

\section{DISCUSSION}

Phytochemical screening of this plant was executed with the consideration of the type of solvent used for extraction [24]. The structures of compounds determine their solubility in the solvent polarity [25]. Therefore, it is very important to isolate non-polar compounds with non-polar solvents and polar compounds with polar solvents [26]. In the current study, acetone, methanol, and water were used as solvents for extractions. Water extracted the highest percentage yield of $K$. africana extract. In most studies, methanol yielded highest percentage of crude extract [27]. Our phytochemical screening revealed the presence of phenolic compounds, flavonoids, and antioxidants.

Phenolic compounds constitute one of the main classes of secondary metabolites in plants [28]. They possess the antioxidant properties that protect against damaging effect of free radical scavenging activity [29]. They are believed to account for the AA of most plant species [30]. From the results, acetone extracts of $K$. africana contained a significantly high total phenolic content and total flavonoid content among the extracts tested. The results concur with the findings from Eloff and McGaw [31], where they reported that acetone extracts are considered to be good extracts for many medicinal plant metabolites.

Numerous methods have been developed to measure the radical scavenging activity of antioxidants in food extracts, beverages, and plant extracts. DPPH and 2, 2'-azinobis-3-ethylbenzothiazolinesulfonic acid scavenging assays are one of the most popular spectrophotometric methods used to evaluate the AA of samples. These methods are simple to use and rapid to assess the AA but 
very sensitive to light [32]. In this study, DPPH radical assay was used to determine the AA of $K$. africana extracts. DPPH radical is a purple color compound. On reaction with antioxidant, it decolorizes to light yellow diphenyl-2-picrylhydrazine by accepting hydrogen atom from antioxidants [33]. The degree of color change at the end of the reaction is proportional to the free radical scavenging activity of antioxidants [34]. In our study, methanol extract of $K$. africana effectively reduced the DPPH radical of all the extracts tested and ascorbic acid. The presence of lower IC $_{50}$ value indicated the stronger AA against damaging free radicals [35]. AA could be due to the presence of higher phenolic compounds; however, methanol extract of $K$. africana contained the lowest total phenolic and flavonoid contents than acetone extract. Therefore, the results suggest that there is no relationship between the amount of phenolic compounds and AA. Our findings are in line with the study by Adebayo et al. [14] which reported poor relationship between total phenolic contents and AA.

Apart from phenolic compounds, it was reported that the AA could be due to other bioactive compounds in the extracts [36]. Glycosides, phenolic compound, saponin, tannins, alkaloids, flavonoids, and sugar have been found in the methanol and water extracts of K. Africana [37]. Moreover, the AA also depended on the chemical structure of the antioxidants and interaction occurring between them and other plant constituents [38,39]. For these reasons, it is important to consider other compounds contributing to curative effect of medicinal plants and their mechanism.

MTT assay is a commonly used assay for the detection of cell viability and cytotoxicity after exposure to toxic substances [40]. MTT is a water-soluble yellow tetrazolium salt which is converted to waterinsoluble purple formazan product when incubated with viable cells. The MTT formazan product is impermeable to the cell membrane of dead cells but accumulates in healthy cells. The formazan product is formed when tetrazolium ring is cleaved by mitochondria succinate dehydrogenase enzyme of viable cells. For this reason, the intensity of MTT formazan produced is directly proportional to the number of viable cells tested [22]. Acetone and methanol extracts of $K$. africana showed higher percentage of viable cells at $1 \mathrm{mg} / \mathrm{ml}$, the highest concentration, whereas water extract had the higher percentage of viable cells at $0.25 \mathrm{mg} / \mathrm{ml}$. This was also observed by Opuwari and Monsees [41], who reported the concentration-dependent increased percentage cell viability from 250 to $1000 \mu \mathrm{g} / \mathrm{ml}$ when TM3 Leydig cells were exposed to Camellia sinensis (unfermented and unfermented rooibos) and Aspalathus linearis (green and black tea), but reduced at $5000 \mu \mathrm{g} / \mathrm{ml}$.

In terms of cytotoxicity, water extract of $K$. africana showed lowest cytotoxicity against TM3 Leydig cells. Based on this finding, it appears that water extract of $K$. africana is less toxic but may be depended on the type of the cell. Basically, traditional healers use water as solvent to prepare medicinal concoctions [27]. It can, therefore, be conceivable to conclude that traditional healers could be encouraged to continue to use water as solvent for their extractions.

Leydig cells lie between the seminiferous tubules in the testes and their main physiological function is to produce and secrete testosterone [42]. Testosterone maintains and regulates spermatogenesis [43]. The TM3 Leydig cells were used in this present study to examine the effects of varying concentrations of $K$. africana extracts in testosterone production. After $24 \mathrm{~h}$ exposure to different concentrations of $K$. africana extracts and anti-hCG, acetone and methanol extracts of K. africana caused increase in testosterone production by TM3 Leydig cells. At the higher concentration, acetone extract caused a significant increase in testosterone level than in the control A. Methanol and water extracts of $K$. africana caused increase in testosterone levels in a concentration-dependent fashion. The results concur with findings reported by Petersen et al. [44], where $K$ africana fruit extracts were found to cause the increase in testosterone levels and folliclestimulating hormone.

\section{CONCLUSION}

K. africana can be regarded as reliable and cheaper source of natural antioxidants. The results showed significant levels of phenolic and flavonoid contents in this plant. Due to low cytotoxicity, the plant can also be recommended to traditional healers to use as additional plant for the treatment of various ailments, especially those that are aggravated by reactive oxygen species, such as diabetes and male infertility.

\section{AUTHORS' CONTRIBUTIONS}

Nelisiwe Masuku, as the first author, was involved designing the work, performing experiments, data analysis, data interpretation, and drafting the manuscript. Sogolo Lebelo, as the corresponding author, was involved in conceptualization of the research project, critical revision of the manuscript and approval, and submission of the final manuscript.

\section{CONFLICTS OF INTEREST STATEMENT}

The authors declare that there are no conflicts of interest.

\section{ACKNOWLEDGMENTS}

The authors would like to thank Mr. PM Dikhoba for assisting in with some of the laboratory procedures in this study. We would like to convey our gratitude to the National Research Foundation, Unisa Research Administration section, and National Student Aid Scheme for funding this project and sincere thanks to University of the Western Cape researchers for providing cell lines for this study.

\section{REFERENCES}

1. Patel SK, Singh S, Singh HK, Singh SK. Effect of standardized extract of Bacopa monnieri (CDRI-08) on testicular functions in adult male mice. J Ethnopharmacol 2017;197:101-9.

2. WHO EB134/24. Traditional Medicine. Executive Board, $134^{\text {th }}$ Session; Provisional Agenda Item 9.1. 2013

3. Wojdyło A, Oszmiański J, Czemerys R. Antioxidant activity and phenolic compounds in 32 selected herbs. Food Chem 2007;105:940-9.

4. Ansari N, Chande D. Antioxidant studies on methanol and aqueous extracts of Gymnosporia montana plant. Int J Pharm Pham Sci 2019;11:65-70

5. Shalaweh SM, Erasmus N, Weitz F, Henke RR. Effect of Cissampelos capensis rhizome extract on human spermatozoa in vitro. Int J Androl 2014;20:1-10.

6. Ebrahim M, Pool EJ. The effect of Tulbaghia violacea extracts on testosterone secretion by testicular cell cultures. J Ethnopharmacol 2010;132:359-61.

7. Van Wyk BE. Medicinal Plants of South Africa. $2^{\text {nd }}$ ed. Pretoria, South Africa: Briza; 2009. p. 184-5.

8. Pratima H. Antioxidant and antibacterial activity of alkaloid extract of Cucumis trigonus Roxb. Int J Pharm Pharm Sci 2019;11:44-8.

9. Lim TK. Fruits. In: Edible Medicinal and Non-Medicinal Plants. Vol. 2. Netherlands: Springer; 2012. p. 401.

10. Saini S, Kaur H, Verma B, Ripudaman S, Eloff NJ. Kigelia africana (Lam.) Benth an overview. Nat Prod Rad 2009;8:190-7.

11. Würger G, McGaw LJ, Eloff JN. Tannin content of leaf extracts of 53 trees used traditionally to treat diarrhoea is an important criterion in selecting species for further work. S Afr J Bot 2014;90:114-7.

12. Watt JM, Breyer-Brandwijk MG. The Medicinal and Poisonous Plants of Southern and Eastern Africa. $2^{\text {nd }}$ ed. Edinburgh: E. and S. Livingstone Ltd.; 1962.

13. Makkar HP. Quantification of tannin in tree foliage. A Laboratory Manual For The Faq/Iaea Co-Ordinated Research Project on use for Nuclear and Related Techniques to Develop Simple Tannin Assay for Predicting and Improving the Safety and Efficiency of Feeding Ruminants on the Tanniferous Tree Foliage. Vienna, Austria: Joint FAQ/IAEA Division of Nuclear Techniques in Food and Agriculture, Vienna; 1999

14. Adebayo SA, Dzoyem JP, Shai LJ, Eloff JN. The anti-inflammatory and antioxidant activity of 25 plant species used traditionally to treat pain in Southern African. BMC Complement Altern Med 2015;15:159.

15. Parthasarathy S, Bin Azizi J, Ramanathan S, Ismail S, Sasidharan S, Said MI, et al. Evaluation of antioxidant and antibacterial activities of aqueous, methanolic and alkaloid extracts from Mitragyna speciosa (Rubiaceae family) leaves. Molecules 2009;14:3964-74. 
16. Yadav RN, Agarwal M. Phytochemical analysis of some medicinal plants. J Phytol 2011;3:10-14.

17. Miliauskas G, Venskutonis PR, Van Beek TA. Screening of radical scavenging activity of some medicinal and aromatic plant extracts. Food Chem 2004;85:231-7.

18. Mensor LL, Menezes FS, Leitão GG, Reis AS, dos Santos TC, Coube CS, et al. Screening of Brazilian plant extracts for antioxidant activity by the use of DPPH free radical method. Phytother Res 2001;15:127-30.

19. Hamzah RU, Jigam AA, Makun HA, Egwin EC. Phytochemical screening and in vitro antioxidant activity of methanolic extract of selected Nigerian vegetables. Asian J Basis Appl Sci 2014;1:1-14.

20. Monsees TK, Franz M, Gebhardt S, Winterstein U, Schill WB, Hayatpour J, et al. Sertoli cells as a target for reproductive hazards. Andrologia 2000;32:239-46.

21. Mahapatra A, Mativandlela SP, Binneman B, Fourie PB, Hamilton CJ, Meyer JJ, et al. Activity of 7-methyljuglone derivatives against mycobacterium tuberculosis and as subversive substrates for mycothiol disulfide reductase. Bioorg Med Chem 2007;15:7638-46.

22. Mosmann T. Rapid colorimetric assay for cellular growth and survival: Application to proliferation and cytotoxicity assays. J Immunol Methods 1983;65:55-63.

23. Fadipe VO, Mongalo NI, Opoku AR. In vitro evaluation of the comprehensive antimicrobial and antioxidant properties of Curtisia dentata (Burm.f) C.A. Sm: Toxicological effect on the human embryonic kidney (HEK293) and human hepatocellular carcinoma (HepG2) cell lines. EXCLI J 2015; 14:971-83.

24. Masoko P, Mmushi TJ, Mogashoa MM, Mokgotho MP, Mampuru LJ, Howard RL. In vitro evaluation of the antifungal activity of Sclerocarya birrea extracts against pathogenic yeasts. Afr J Biotechnol 2008;7:3521-6.

25. Złoteck U, Mikulska S, Nagajek M, Świeca M. The effect of different solvents and number of extraction steps on the polyphenol content and antioxidant capacity of basil leaves (Ocimum basilicum L.) extracts. Saudi J Biol Sci 2016;23:628-33.

26. Nemudzivhadi V, Masoko P. Antioxidant and antibacterial properties of Ziziphus mucronata and Ricinus communis leaves extracts. Afr J Tradit Comp Alt Med 2015;12:81-9.

27. Masoko P, Picard J, Eloff JN. Antifungal activities of six South African Terminalia species (Combretaceae). J Ethnopharmacol 2005;99:301-8.

28. Klimczak I, Malecka M, Gliszcyńska-Świglo A. Effect of storage on the content of polyphenols, vitamins and the antioxidant activity of orange juices. J Food Compos Anal 2007;20:313-22.

29. Tahara S. A journey of twenty-five years through the ecological biochemistry of flavonoids. Biosci Biotechnol Biochem 2007;71:1387-404
30. Giorgi A, Mingozzi M, Madeo M, Speranza G, Cocucci M. Effect of nitrogen starvation on the phenolic metabolism and antioxidant properties of yarrow (Achillea collina Becker ex Rchb.) Food Chem 2009;114:204-11.

31. Eloff JN, McGaw LJ. Plant extracts used to manage bacterial, fungal and parasitic infections in Southern Africa. In: Ahmad I, Owais M, editors. Modern Phytomedicine: Turning Medicinal Plants into Drugs. Weinheim: Wiley-VCH Verlag GmbH and Co. KGaA; 2006. p. 113.

32. Ak T, Gülçin I. Antioxidant and radical scavenging properties of curcumin. Chem Biol Interact 2008;174:27-37.

33. Floegel A, Kim DO, Chung SJ, Koo SI, Chun OK. Comparison of ABTS/DPPH assays to measure antioxidant capacity in popular antioxidant-rich US foods. J Food Compos Anal 2011;24:1043-8.

34. Krishnaiah D, Sarbatly R, Nithyanandam R. A review of the antioxidant potential of medicinal plant species. Food Bioprod Process 2011;89:217-33

35. Do QD, Angkawijaya AE, Tran-Nguyen PL, Huynh LH, Soetaredjo FE, Ismadji S, et al. Effect of extraction solvent on total phenol content, total flavonoid content, and antioxidant activity of Limnophila aromatica. J Food Drug Anal 2014;22:296-302.

36. EI-Chaghaby GA, Ahmad AF, Ramis ES. Evaluation of the antioxidant and antibacterial properties of various solvents extracts of Annona squamosal L. leaves. Arabian J Chem 2014;7:227-33.

37. Abdulkadir MN, Adedokun A, John E. Phytochemical composition and antimicrobial evaluation of Kigelia africana LAM. Asian J Plant Sci Res 2015;5:14-7.

38. Galano A, Mazzone G, Alvarez-Diduk R, Marino T, Alvarez-Idaboy JR, Russo N, et al. Food antioxidants: Chemical insights at the molecular level. Annu Rev Food Sci Technol 2016;7:335-52.

39. Nimse SB, Pal D. Free radicals, natural antioxidants, and their reaction mechanisms. RSC Adv 2015;5:27986-8006.

40. Fotakis G, Timbrell JA. In vitro cytotoxicity assays: Comparison of LDH, neutral red, MTT and protein assay in hepatoma cell lines following exposure to cadmium chloride. Toxicol Lett 2006;160:171-7.

41. Opuwari CS, Monsees TK. Reduced testosterone production in TM3 leydig cells treated with Aspalathus linearis (Rooibos) or Camellia sinensis (tea). Andrologia 2015;47:52-8.

42. Petersen PM, Seierøe K, Pakkenberg B. The total number of leydig and sertoli cells in the testes of men across various age groups a stereological study. J Anat 2015;226:175-9.

43. Walker WH. Testosterone signaling and the regulation of spermatogenesis. Spermatogenesis 2011;1:116-20.

44. Azu OO, Duru FI, Osinubi AA, Noronha CC. Histomorphometric effects of Kigelia africana (Bignoniaceae) fruit extract on the testis following short-term treatment with cisplatinin male sprague-dawley rats. Mid East Fert Soc J 2010;15:200-8. 